Teresa Kurowska

\title{
Założenia konstrukcyjne umowy przyznania pomocy z Europejskiego Funduszu Rolnego na rzecz Rozwoju Obszarów Wiejskich
}

\section{Uwagi wprowadzające}

W polskim systemie prawnym umowa przez długi czas stanowiła podstawowy instrument regulowania złożonych stosunków dotyczących obrotu ziemią, a przede wszystkim związanych z korzystaniem z gruntów rolnych i innych dóbr związanych z rolnictwem, W sektorze rolnym, jak w żadnej innej dziedzinie gospodarki, umowy rolnicze (kontrakt rolny) powinny odzwierciedlać ich społeczny charakter, bowiem są wykorzystywane do porządkowania i godzenia różnorodnych interesów. Stosowane w polskim obrocie rolnym umowy mają bardzo zróżnicowany charakter i mogą pełnić różne funkcje. W obrocie powszechnym stosowane będą znane kodeksowi cywilnemu umowy: 1) przeniesienia prawa własności, w tym nieruchomości rolnych, np. umowa sprzedaży, zamiany, darowizny, dożywocia; 2) nabycia innego niż własność tytułu prawnego do nieruchomości, np. umowa dzierżawy, najmu, użytkowania czy też 3) nabycia innych składników majątkowych wchodzących w skład gospodarstwa rolnego służących organizacji procesu produkcyjnego, jak np. umowa kontraktacji, leasingu, dostawy, umowa o roboty budowlane. W praktyce wymienione umowy są zawierane w celu utworzenia lub powiększenia oraz organizacji gospodarstwa rolnego z przedmiotowego punktu widzenia. Nadto, takie mowy jak umowa darowizny, dożywocia, sprzedaży są wykorzystywane w procesie zmiany pokoleń w rolnictwie. $Z$ kolei celem występujących w obrocie rolnym umów pozakodeksowych (specjalnych) jest ułatwienie lub przyspieszenie tego obrotu, jak np. umowa z następcą, umowa przekazania gospodarstwa rolnego za rentę strukturalną ${ }^{1}$ czy też przyspieszenie przemian strukturalnych $\mathrm{w}$ rolnictwie $\mathrm{z}$ wykorzystaniem nowego rodzaju umów obligacyjnych, jakim są tzw. umowy przyznania pomocy, konstruowane w celu uzyskania pomocy finansowej ze środków wspólnotowych w ramach programów wsparcia rozwoju obszarów wiejskich. Są to umowy celowe 
zawierane z podmiotami prowadzącymi gospodarstwo rolne, których przedmiotem jest: 1) modernizacja gospodarstw, ich różnicowanie w kierunku działalności pozarolniczej, zwiększenie produkcji dodanej podstawowej produkcji rolnej i leśnej, 2) tworzenie i rozwój mikroprzedsiębiorstw oraz 3) świadczenie usług technicznych, szkoleniowych, promocyjnych i informacyjnych dla rolników, a także 4) przeprowadzanie szkoleń zawodowych dla osób zatrudnionych w rolnictwie i leśnictwie; korzystanie z usług doradczych przez rolników i posiadaczy lasów.

Umowy przyznania pomocy stanowią cywilnoprawny instrument wspierania działań ułatwiających dywersyfikację produkcji w gospodarstwach rolnych, co wpływa na wzrost ich dochodowości, wyrównywanie różnic w gospodarstwach rolnych, podnoszenie kwalifikacji zawodowych rolników oraz wyrównywanie szans rozwoju społeczności lokalnych na obszarach wiejskich.

\section{Charakter prawny umowy przyznania pomocy}

Podstawę prawną dla konstruowania umowy przyznania pomocy stanowią przepisy art. 8-13, art. 18, art. 22-23, art. 25-28, art. 30-33, a zwłaszcza art. $23 \mathrm{w}$ związku z art. 22 ust. 1 ustawy z dnia 7 marca 2007 r. o wspieraniu rozwoju obszarów wiejskich z udziałem środków Europejskiego Funduszu Rolnego na rzecz Rozwoju Obszarów Wiejskich ${ }^{2}$ oraz przepisów wykonawczych do ustawy. Poza postanowieniami istotnymi określonymi w art. 23 ustawy - takich jak: oznaczenie przedmiotu i stron umowy; określenie warunków, terminu i miejsca realizacji operacji; określenia wysokości pomocy; określenia warunków i terminów wypłaty środków finansowych z tytułu pomocy; określenia warunków rozwiązania umowy; określenia warunków sposobu zwrotu środków finansowych z tytułu pomocy, w przypadku gdy pomoc jest nienależna lub wypłacona w nadmiernej wysokości - umowa może zawierać dodatkowe postanowienia dotyczące realizacji operacji określone w rozporządzeniu wykonawczym. ${ }^{3} \mathrm{~W}$ szczególności będą to: 1) zobowiązanie beneficjenta dotyczące: osiągnięcia celu operacji i zachowania tego celu przez 5 lat, licząc od dnia wypłaty świadczenia pieniężnego przez Agencję; 2) niefinansowania operacji z udziałem innych środków publicznych; 3) ograniczeń lub warunków w zakresie: a) przenoszenia własności nieruchomości lub posiadania rzeczy nabytych w ramach realizacji operacji lub sposobu ich wykorzystania; b) sposobu lub miejsca prowadzenia działalności związanej z przyznaną pomocą - przez okres 5 lat - licząc od dnia dokonania płatności przez Agencję; 4) umożliwienia przeprowadzenia kontroli związanych z przyznaną pomocą przez okres 5 lat - licząc od dnia dokonania przez Agencję płatności; 5) przechowywania dokumentów związanych z przyznaną pomocą przez okres 5 lat - licząc od dnia dokonania przez Agencję płatności; 6) infor-

Dz.U. Nr 64, poz. 427 ze zm.; zwana w skrócie u.w.r.ow.z. UFR ROW

Por. bliżej na temat ograniczeń swobody umów R. Trzaskowski, Granice swobody kształtowania treści i celu umów obligacyjnych. Art. $353^{1}$ kc., Kraków 2005, s. 207-210. 
mowania Agencji o okolicznościach mogących mieć wpływ na wykonanie umowy przez okres pięciu lat - licząc od dnia dokonania przez Agencję płatności, a także 7) postanowienia dotyczące warunków i sposobu pozyskiwania przez Agencję od beneficjenta danych określonych w art. 7 ust. 4 ustawy $y^{4}$.

Umowa przyznania pomocy jest umową cywilnoprawną, którą możemy zaliczyć do umów rolnych, do której mają odpowiednio zastosowanie przepisy kodeksu cywilnego. Jest to umowa nienazwana, zobowiązująca, konsensualna, wzajemna, dla której zastrzeżono, pod rygorem nieważności, formę pisemną ad solemnitatem (art. 22 ust. 1 w.w.r.o.w.z. EFR ROW). W obrocie rolnym jej treść znalazła wyraz we wzorcach umów przyznania pomocy ${ }^{5}$ na działania określone w art. 5 ust. 1, 4, 5, 8 u.w.r.o.w.z. EFR ROW. Szczegółowe postanowienia tychże wzorców umów zostały kazuistycznie uregulowane z uwzględnieniem przepisów art. 22 ust. 1 i 2, art. 23, 27-37 tejże ustawy oraz przepisów wykonawczych dla poszczególnych działań. ${ }^{6}$ Wzorzec umowy przyznania pomocy jest dokumentem istniejącym niezależnie od konkretnej umowy wyznaczającym treść stosunku zobowiązaniowego. Wiąże strony umowy po jego doręczeniu przed zawarciem umowy (art. 384 kc.). Zdaniem doktryny prawa cywilnego wzorzec umowy nie uchybia zasadzie swobody umów (art. $353^{1} \mathrm{kc}$.), faktycznie wywiera wpływ na jej zacieśnienie, albowiem jej treść jest ściśle ustalona, a strony przychylając się do niej, przyjmują ją za wyraz swojej woli. Sąd Najwyższy uznał za dopuszczalne ustalenie treści stosunku zobowiązaniowego w odniesieniu do zagadnień, które ustawa normuje w sposób imperatywny. ${ }^{7}$ Zatem swoboda umów doznaje ograniczenia m.in. w takim zakresie, w jakim przewidują to przepisy ustawy z 7.03.2007 r. o wspieraniu rozwoju obszarów wiejskich oraz rozporządzenia wykonawczego. Ustawa wprowadza zasadę, iż zawarta umowa przyznania pomocy może ulec zmianie w trakcie jej wykonywania - na wniosek obu stron umowy - z wyłączeniem możliwości zmiany nie tylko jej istotnych postanowień, ale i niektórych postanowień dodatkowych (tj. zwiększenia wysokości pomocy, celu operacji, zmiany zobowiązania o niefinansowanie operacji z innych środków publicznych). Zmiana strony umowy jest dopuszczalna tylko w wyjątkowych okolicznościach, ściśle w ustawie określonych, za zgodą jednostki wdrażającej. Nie-

4 Por. § 21 ust. 2 rozporządzenia Ministra Rolnictwa i Rozwoju Wsi z dnia 7.10.2007 r. w sprawie szczegółowych warunków i trybu przyznawania pomocy finansowej w ramach działania „Modernizacja gospodarstw rolnych” objętego Programem Rozwoju Obszarów Wiejskich na lata 2007-2013 (Dz.U. Nr 193, poz. 1397).

$5 \S 21$ ust. 1 rozporządzenia op. cit. stanowi podstawę dla opracowania wzorca umowy przyznania pomocy. $Z$ jego treści wynika wprost „Umowę zawiera się na formularzu opracowanym przez Agencję i udostępnionym na stronie internetowej Agencji." Na temat kształtowania treści stosunku prawnego przez wzorzec umowy por. bliżej M. Bednarek, Wzorce umów w prawie polskim, Warszawa 2005, s. 73-77 i podana tam obszerna literatura.

$6 \quad$ Por. m.in. $\S 21$ ust. 1 rozporządzenia op. cit., a także $\S 17$ ust. 1 rozporządzenia tegoż z dnia 17.10 .2007 r. w sprawie szczegółowych warunków i trybu przyznawania pomocy finansowej w ramach działania „Zwiększenie wartości dodanej podstawowej produkcji rolnej i leśnej”. Dz.U. Nr 200, poz. 1444. Rozporządzenia wykonawcze do ustawy wydano do wszystkich działań wymienionych w cytowanym art. 5 ustawy z 7.03.2007 r. Wskazane przepisy zobowiązuja jednostkę wdrażającą do zawierania umów według opracowanego wzorca umowy, udostępnionego na jej stronie internetowej. Por. wyrok SN z 16.02.2001 r. IV CKN 244/00, OSNC 2001, nr 9, poz. 138. 
wątpliwie są to ustawowe ograniczenia zasady swobody umów. ${ }^{8}$ Taka umowa związana jest z potrzebą standaryzacji treści zobowiązań umownych i jest przyjmowana w praktyce obrotu cywilnego, w tym obrotu rolnego.

W latach 70-tych XX wieku w polskim ustawodawstwie prawnorolnym funkcjonowały - podobne w swoim charakterze prawnym, lecz o odmiennym celu umowy kooperacyjne. W literaturze wskazywano na ich cywilnoprawny charakter z uwagi na następujące cechy umów: ramowość treści, dobrowolność zawierania przez strony, właściwość sądów powszechnych w zakresie rozstrzygania sporów z umów kooperacyjncyh. ${ }^{9}$ Umowa przyznania pomocy jest niejako narzucana przez silniejszą stronę - organ rządowy delegujący swoje kompetencje instytucjom wdrażającym (zarządzającym). Swoboda beneficjenta (strony umowy) jest ograniczona do minimum. Może on zawrzeć umowę na zasadzie dobrowolności, lecz o treści wskazanej przez instytucję wdrażającą bądź zrezygnować z jej zawarcia. Niewątpliwie jest to typ umowy adhezyjnej, albowiem zawarcie umowy następuje przez przystąpienie do warunków określonych w treści wzorca umowy przedstawionego przez stronę silniejszą ekonomicznie (dominująca). Art. $384 \mathrm{kc}$. normuje formalne przesłanki związania wzorcem umowy adherenta (beneficjenta). Podstawowym obowiązkiem Agencji jest doręczenie wzorca na piśmie beneficjentowi przed zawarciem umowy. Wyłonienie przyszłego oblata (strony umowy przyznania pomocy) poprzedzone jest szczególnym postępowaniem administracyjnym, z wniosku beneficjenta o przyznanie pomocy w ramach konkretnego działania. Czynność administracyjnoprawna zatwierdzenia wniosku przez podmiot wdrażający jest z jednej strony aktem wiedzy ${ }^{10}$ organu publicznego potwierdzającym spełnienie przesłanek wymaganych przepisami ustawy z dnia 7.03.2007 r. oraz konkretnego rozporządzenia wykonawczego. $Z$ drugiej strony - w przypadku pozytywnego rozstrzygniecia wniosku - stanowi źródło powstania stosunku zobowiązaniowego, gdyż konkretyzuje przyszłego oblata (beneficjenta), któremu proponent (Agencja) zobowiązana jest do niezwłocznego złożenia pisemnej oferty załączonego wzorca umowy, co oznacza, że oferta powinna zostać przyjęta przez oblata bez zastrzeżeń (art. 385 kc.), a umowa zawarta w wyznaczonym 14-dniowym terminie, licząc od dnia jej doręczenia ${ }^{11}$. W przypadku negatywnego rozstrzygnięcia wniosku czynność taka sta-

8 Por. także T. Wiśniewski, (w:) Komentarz do Kodeksu cywilnego. Księga 3, Zobowiązania, tom 1, Warszawa 2007, wyd. 8, s. 20-24.

9 Por. bliżej A. Lichorowicz, Umowa międzysektorowej kooperacji produkcyjnej w rolnictwie. Wrocław 1979, s. $41-$ 49.

10 W judykaturze zagadnienie to było przedmiotem rozstrzygnięcia zagadnienia wstępnego na podstawie ustawy z dnia 28 maja 1957 r. o sprzedaży przez Państwo domów mieszkalnych i działek budowlanych (Dz.U. Nr 31, poz. 132) w uchwale SN z dnia 25 kwietnia 2964 r. (III CO 12/64, OSP i KA 1/1965), a także NSA w uchwale z dnia 29 marca 2006 r. (II GPS 1/2006, OSP 2006/1) na podstawie przepisów ustawy z dnia 27 sierpnia 1997 r. o rehabilitacji zawodowej i społecznej oraz zatrudnieniu osób niepełnosprawnych (Dz.U. Nr 123, poz. 776 ze $\mathrm{zm}$.)

$11 \S 16$ ust. 1 i 2 rozporządzenia wykonawczego Por. także M Bednarek, Wzorce umów..., s. 129 i n. 
nowi podstawę odmowy zawarcia umowy. ${ }^{12}$ Wzorzec umowy, jako oświadczenie woli proponenta (Agencji), podlega wykładni na podstawie art. $65 \S 1 \mathrm{kc}$. Przepisy rozporządzenia wykonawczego dopuszczają przyjęcie oferty w innym uzgodnionym z Agencją terminie, jednak przed upływem wyznaczonego w treści oferty, nie dłuższym jednak niż 1 miesiąc lub 21 dni, licząc od dnia, na który został wyznaczony poprzedni termin przyjęcia oferty i zawarcia umowy w terminie wyznaczonym przez Agencję. Upływ wyznaczonego lub uzgodnionego z Agencją terminu do przyjęcia oferty i zawarcia umowy lub złożenie przed upływem tychże terminów oświadczenia beneficjenta o odrzuceniu oferty skutkuje odmową przyznania pomocy. Zauważyć wypada, że poza umową przyznania pomocy taka pomoc udzielana jest także w formie decyzji administracyjnej. ${ }^{13}$

Stronami umowy przyznania pomocy są: podmiot wdrażający (zarządzający) oraz beneficjent.

W zależności od określonego ustawą z 7.03.2007 r. działania, podmiotem wdrażającym jest:

1. Agencja Restrukturyzacji i Modernizacji Rolnictwa - w odniesieniu do działań: modernizacja gospodarstw rolnych, zwiększenie wartości dodanej podstawowej produkcji rolnej i leśnej; korzystanie z usług doradczych przez rolników; różnicowanie w kierunku działalności nierolniczej; tworzenie i rozwój mikroprzedsiębiorstw; pomoc techniczna;

2. Agencja Rynku Rolnego - w odniesieniu do działań informacyjnych i promocyjnych;

3. Zarząd województwa samorządowego - w odniesieniu do działań: podstawowe usługi dla gospodarki i ludności wiejskiej; odnowa i rozwój wsi; wdrażanie lokalnych strategii rozwoju, wdrażanie projektów współpracy; funkcjonowanie lokalnej grupy działania oraz

4. Jednostki doradztwa rolniczego, izby rolnicze oraz podmioty, które uzyskały akredytację ministra ds. rozwoju wsi - w odniesieniu do działań: szkole-

Co do charakteru prawnego tej czynności admnistracyjnoprawnej zarówno w doktrynie jak i orzecznictwie obserwujemy rozbieżność poglądów. Są one aktualne także na podstawie przepisów omawianej ustawy z 7 marca 2007 r. o.w.r.o.w.z. EFR ROW. Por. J. Jagoda, Uchwała organu jednostki samorządu terytorialnego jako czynność poprzedzająca zawarcie umowy cywilnoprawnej, (w:) Umowy w administracji. Pod red. J. Bocia, L. DziewięckiejBokun, Wrocław 2008, s. 560

13 Na następujące działania: ułatwianie startu młodym rolnikom; renty strukturalne; poprawianie i rozwijanie infrastruktury związanej z rozwojem i dostosowaniem rolnictwa i leśnictwa przez: a) scalanie gruntów; b) gospodarowanie rolniczymi zasobami wodnymi; wspieranie gospodarstw rolnych niskotowarowych w fazie restrukturyzacji; grupy producentów rolnych; wspieranie gospodarowania na obszarach górskich i innych obszarach o niekorzystnych warunkach gospodarowania (ONW); płatności dla obszarów NATURA 2000 oraz zwiazanych z wdrażaniem Ramowej Dyrektywy Wodnej; program rolno-środowiskowy; zalesianie gruntów rolnych oraz zalesianie gruntów innych niż rolne; odtwarzanie potencjału produkcji leśnej zniszczonego przez katastrofy oraz wprowadzenie instrumentów zapobiegawczych. (art. 5 ust. 1 pkt 2, 3, 6, 9, 10, 12-16 u. w.r.o.w. z EFR ROW). 
nia zawodowe dla osób zatrudnionych w rolnictwie i leśnictwie; korzystanie z usług doradczych przez rolników i posiadaczy lasów.

Trzy pierwsze podmioty - strony umowy przyznania pomocy - wykonują swoje zadania z mocy ustawy (art. 6 ust. 1 pkt $2,3,4^{14}$ ), zaś podmioty wymienione w pkt. 1.4 są wyłaniane na podstawie art. 36 ustawy w drodze konkursu ofert. ${ }^{15}$ Tej z nich, która uzyskała najwyższą punktację zespołu akredytacyjnego ${ }^{16}$ minister właściwy ds. rozwoju wsi udziela akredytacji (mocą decyzji administracyjnej), a następnie zawiera z nią umowę przyznania pomocy na szkolenia. Z kolei podmiot akredytowany zawiera $\mathrm{z}$ beneficjentem umowę o świadczenie usług szkoleniowych lub zawodowych.

Zakres podmiotowy stron umów przyznania pomocy (beneficjentów) jest szeroko określony dla takich działań, jak: operacje modernizacyjne, szkoleniowe, promocyjne, techniczne w gospodarstwie rolnym czy też o charakterze lokalnych działań ludności wiejskiej. Będą to osoby fizyczne, osoby prawne lub jednostki organizacyjne nieposiadające osobowości prawnej, mające status rolnika lub przedsiębiorcy albo lokalnej grupy działania pod warunkiem spełnienia przesłanek wymaganych w przepisach wykonawczych dla poszczególnych działań objętych pomocą.

\section{Umowa przyznania pomocy na realizację operacji w ramach Programu w zakresie osi 1 „Poprawa konkurencyjności sektora rolnego i leśnego” działania „Modernizacja gospodarstw rolnych”}

Umowy wzorcowe przyznania pomocy na poszczególne działania są zróżnicowane w zakresie podmiotowym oraz przedmiotowym, warunków i miejsca realizacji operacji, wysokości pomocy, dlatego też uzasadnione będzie ograniczenie przedmiotu szczegółowych rozważań do przedstawienia założeń konstrukcyjnych jednej z najbardziej rozbudowanych umów - umowy przyznania pomocy na realizację operacji w ramach Programu w zakresie osi 1 „Poprawa konkurencyjności sektora rolnego i leśnego” działania „Modernizacja gospodarstw rolnych”.

\section{Strony umowy}

1.1. Agencja Restrukturyzacji i Modernizacji Rolnictwa (podmiot wdrażający posiadający status Agencji płatniczej), reprezentowana przez Dyrektora Oddziału Regionalnego Agencji właściwego ze względu na miejsce reali-

W zakresie określonym rozporządzeniem Ministra Rolnictwa i Rozwoju Wsi z dnia 6.08.2007 r. w sprawie szczegółowego określenia zakresu zadań instytucji zarządzającej wykonywanych przez niektóre podmioty jako zadania delegowane oraz sposób ich wykonywania w ramach Programu Rozwoju Obszarów Wiejskich na lata 20072013. Dz.U. Nr 150, poz. 1067. przesłanki, m.in. udokumentować, że usługi będą świadczone przez osoby posiadające kwalifikacje i doświadczenie w realizacji usług doradczych danego rodzaju (art. 36 ust. 2 pkt 2 ustawy). Zespół akredytacyjny jest powoływany przez ministra właściwego ds. rozwoju wsi. 
zacji operacji, działającego na podstawie pełnomocnictwa ogólnego Prezesa Agencji.

1.2. Beneficjent, osoba fizyczna spełniająca następujące warunki:

a) jest posiadaczem samoistnym lub zależnym gospodarstwa rolnego ${ }^{17} \mathrm{~W}$ rozumieniu art. $55^{3} \mathrm{kc}$., o powierzchni użytków rolnych co najmniej 1 ha lub nieruchomości służącej do prowadzenia produkcji w zakresie działów specjalnych produkcji rolnej w rozumieniu art. 6 pkt 5 ustawy z 20 grudnia 1990 r. o ubezpieczeniu społecznym rolników ${ }^{18}$; wielkość ekonomiczna gospodarstwa stanowi równowartość 4 ESU ${ }^{19}$,

b) prowadzi na terytorium Rzeczypospolitej Polskiej produkcję roślinną lub zwierzęcą, taksatywnie wyliczoną w $§ 2$ ust. 1 pkt. 2 rozporządzenia ${ }^{20}$, np. produkcję materiału siewnego, szkółkarskiego, hodowlanego lub reprodukcyjnego, produkcję warzywniczą, roślin ozdobnych itd.,

c) jest obywatelem państwa członkowskiego Unii Europejskiej,

d) jest pełnoletnia i nie ukończyła 60 roku życia,

e) posiada kwalifikacje zawodowe (wyższe, średnie, zawodowe lub tytuł kwalifikowany/zawodowy w zawodzie przydatnym do prowadzenia działalności rolniczej i co najmniej 3-letni staż pracy w rolnictwie) lub nierolnicze (wyższe, średnie i co najmniej 3-letni staż pracy w rolnictwie, a w przypadku podstawowego, gimnazjalnego lub zasadniczego zawodowego innego niż rolnicze co najmniej 5-letni staż pracy w rolnictwie) ${ }^{21}$; za staż pracy w rolnictwie uznaje się okres zatrudnienia w gospodarstwie rolnika (jego małżonka, domownika) na podstawie umowy o pracę lub spółdzielczej umowy o pracę związanej z prowadzeniem produkcji rolnej oraz okres, w którym beneficjent był posiadaczem gospodarstwa rolnego; obywatel państwa członkowskiego Unii Europejskiej nieposiadający obywatelstwa polskiego powinien wykazać kwalifikacje rolnicze wymagane dla analogicznego działania współfinansowanego przez Europejski Fundusz Rolny na rzecz Rozwoju Obszarów Wiejskich; na do powierzchni gruntu, a grunt ten stanowi przedmiot posiadania samoistnego i posiadania zależnego, pomoc przysługuje posiadaczowi zależnemu. Natomiast jeśli grunt ten stanowi przedmiot współposiadania pomoc przysługująca temu współposiadaczowi gruntu, co do którego pozostali współposiadacze wyrazili pisemną zgodę. Taka zgoda powinna być dołączona do wniosku o przyznanie pomocy. (art. 18 u.w.r.o.w.z. EFR ROW). bu przyznawania pomocy finansowej w ramach działania „Modernizacja gospodarstw rolnych” objętego Programem Rozwoju Obszarów Wiejskich na lata 2007-2013, Dz.U. Nr 193, poz. 1397 ze zm. 
f) nie podlega wykluczeniu z ubiegania się o pomoc 22 ; w przypadku działania „Ułatwianie startu młodym rolnikom” osoba fizyczna przed złożeniem wniosku o przyznanie pomocy nie ukończyła 40 roku życia. Obywatel państwa członkowskiego UE nieposiadający obywatelstwa polskiego powinien posiadać kwalifikacje wymagane w kraju, którego obywatelstwo posiada;

g) został jej nadany numer identyfikacyjny ${ }^{23}$.

W przypadku, gdy operacja dotyczy wyłącznie gospodarstwa rolnego stanowiącego przedmiot współwłasności osób fizycznych, dla ważności czynności prawnej wymagane jest złożenie na piśmie oświadczenie woli małżonka, współwłaściciela lub współwłaścicieli oraz ich małżonków wyrażających zgodę na zawarcie umowy.

\subsubsection{Osoba prawna:}

a) spełniająca warunki określona dla osoby fizycznej określone w pkt. 1 . ppkt. 2 . 1 lit. a, b, f;

b) wpisana do rejestru przedsiębiorców w Krajowym Rejestrze Sądowym;

c) co najmniej jedna osoba fizyczna wchodząca w skład jej organu zarządzającego posiada wykształcenie określone powyżej w pkt. 1. ppkt. 2. 1 lit. e.

1.2.3. Jednostka organizacyjna nieposiadająca osobowości prawnej mająca status spółki cywilnej ${ }^{24}$, spółki osobowej (w formie spółki jawnej, komandytowej i komandytowo-akcyjnej ${ }^{25}$ ) pod warunkiem, że:

a) wspólnik (w spółce osobowej) będący osobą fizyczną spełnienia przesłanki określone powyżej w pkt. 1. ppkt. 2.1 lit. e, tzn. posiada kwalifikacje zawodowe;

b) wspólnik będący osobą prawną lub jednostka organizacyjna nieposiadająca osobowości prawnej;

c) nie podlega wykluczeniu z ubiegania się o pomoc;

d) została wpisana do rejestru przedsiębiorców w Krajowym Rejestrze Sądowym.

Oba rodzaje spółek nadto winny spełnić następujące przesłanki:

e) wspólnik jest posiadaczem samoistnym lub zależnym gospodarstwa rolnego, przez EFRROW. Dz.Urz. UE L 277 z 21.10.2005, s. 1 ze zm.

W trybie ustawy z dnia 18.12.2003 r. o krajowym systemie ewidencji producentów, ewidencji gospodarstw rolnych oraz ewidencji wniosków o przyznanie płatności. Dz.U. z 2004 r., Nr 10, poz. 76 ze zm.

Regulowanej przepisami art. 860-875 kc. umowy spółki. Spółka cywilna, której przychody netto w każdym z dwóch ostatnich lat obrotowych przekracza równowartość w walucie polskiej 800000 euro, z chwilą wpisu do Krajowego Rejestru Sądowego staje się spółką jawną (art. 26 § 4 i 6 ksh.) 
f) prowadzą w ramach spółki działalność rolniczą na terytorium Rzeczypospolitej Polskiej o wielkości ekonomicznej równowartej 4 ESU;

g) zostały wpisane do rejestru gospodarstw rolnych.

\section{Prawa i obowiązki stron umowy}

2.1. Obowiązkiem Agencji Restrukturyzacji i Modernizacji Rolnictwa (podmiotu wdrażającego) jest: wypłata pomocy ${ }^{26}$ - świadczenia pieniężnego w całości lub częściami (w kilku transzach, nie więcej niż 10, dla inwestycji dwuetapowej lub wieloetapowej realizowanej na podstawie umowy leasingu), w zróżnicowanej, a określonej w umowie wysokości, w zależności od rodzaju operacji, ${ }^{27} \mathrm{w}$ terminie określonym w umowie. Wypłata świadczenia pieniężnego przez Agencję nastąpi niezwłocznie, po upływie 3 miesięcy od dnia złożenia wniosku o płatność. W przypadku wystąpienia opóźnienia w otrzymaniu przez Agencję środków finansowych na wypłatę pomocy, niezwłocznie po ich otrzymaniu.

2.2. Beneficjent zobowiązuje się do: a) realizacji operacji ${ }^{28}$ wieloetapowej (w dwóch lub więcej etapach lub realizowanej na podstawie umowy leasingu, nie więcej jednak niż 10-ciu), której zakres rzeczowy i finansowy określono w zestawieniu rzeczowo-finansowym stanowiącym załącznik do umowy przyznania pomocy; b) spełnienia warunków określonych w Programie oraz przepisach ustawy i rozporządzenia oraz realizacji operacji zgodnie z postanowieniami umowy, a w szczególności: poniesienia kosztów, stanowiących podstawę wyliczenia przysługującej mu pomocy, w formie bezgotówkowej lub gotówkowej (do kwoty 10 tys. zł, z wyłączeniem kupna maszyn lub urządzeń określonych w § 9 ust. 5 rozporządzenia); c) niefinansowania operacji z udziałem innych środków publicznych, przyznanych

Pomoc przyznaje się wyłącznie na operacje obejmujące wyłącznie inwestycje związane z prowadzeniem działalności rolniczej. Jej zakres przedmiotowy określaja przepisy §§ 7-9 rozporządzenia wykonawczego, m.in.: 1) spełniające wymagania określone w Programie; 2) obejmujacce: inwestycje mające na celu dostosowanie gospodarstwa do określonych odrębnymi przepisami wymagań w zakresie: higieny i bezpieczeństwa produkcji oraz warunków utrzymania zwierząt, ochrony środowiska, infrastruktury drogowej itp. związane z budowa, przebudowa, remontem połączonym z modernizacją budynków lub budowli wykorzystywanych do produkcji rolnej, zakupem maszyn, urządzeń, wyposażenia do produkcji rolnej, zakładania, wyposażenia sadów lub plantacji wieloletnich, budowy albo zakupu elementów infrastruktury technicznej wpływającej bezpośrednio na warunki prowadzenia działalności rolniczej oraz koszty ogólne bezpośrednio związane z przygotowaniem i realizacją operacji. Moca $\S 8$ ust. 3 rozporządzenia wykonawczego z zakresu przedmiotowego pomocy wyłączono koszty inne niż wymienione w jego § 9, a w szczególności: 1) nabycie nieruchomości; 2) podatek od towarów i usług; nabycie używanego sprzętu komputerowego.

27 Poziom pomocy może wynosić od $40 \%$ do $75 \%$ kosztów inwestycji kwalifikującej się do objęcia pomoca. Na przykład, wypłata pomocy dla: młodego rolnika oraz realizowanej na obszarach górskich i innych obszarach o niekorzystnych warunkach gospodarowania wynosi 50\% kosztów; realizowanej na obszarach NATURA 2000 wynosi $60 \%$ kosztów, a dla inwestycji realizowanej w związku z wdrażaniem dyrektywy Rady 91/676/EWG z dnia 12 grudnia 1991 r, dotyczącej ochrony wód przed zanieczyszczeniami powodowanymi przez azotany pochodzenia rolniczego, wynosi $75 \%$ kosztów inwestycji kwalifikującej się do objęcia pomocą.

28 Operację stanowi przedsięwzięcie, projekt lub inwestycja, realizowana przez Beneficjenta w ramach działania „Modernizacja gospodarstw rolnych”, w sposób pozwalający na osiagnięcie celów Programu Rozwoju Obszarów Wiejskich na lata 2007-20013 stanowiący załącznik do obwieszczenia Ministra Rolnictwa i Rozwoju Wsi z dnia 12 października 2007 r. w sprawie Programu Rozwoju Obszarów Wiejskich na lata 2007-20013, ogłoszonego w Monitorze Polskim Nr 94, poz. 1035. 
w związku z jej operacją, nadto d) w trakcie operacji oraz przez okres 5 lat od dnia dokonania przez Agencję płatności ostatecznej zobowiązuje się do osiągnięcia i zachowania operacji; e) nieprzenoszenia posiadania lub prawa własności nabytych ruchomości lub wzniesionych (przebudowanych, remontowanych lub zmodernizowanych) na nieruchomości budynków lub budowli trwale z gruntem związanych, na które została przyznana i wypłacona pomoc oraz ich wykorzystania zgodnie z przeznaczeniem i celem operacji; f) prowadzenia działalności, której służyła realizacja operacji, lub której prowadzenie stanowiło warunek przyznania pomocy, bez zmiany miejsca jej wykonania; prowadzenia działalności rolniczej bez zmiany miejsca jej wykonywania; g) niezwłocznego informowania Agencji o planowanych albo zaistniałych zdarzeniach związanych ze zmianą sytuacji prawnej lub faktycznej beneficjenta, jego gospodarstwa lub operacji mających wpływ na: realizację operacji, zgodnie z postanowieniami umowy; wypłatę pomocy lub spełnienia wymagań określonych w Programie, przepisach ustawy i rozporządzenia; h) umożliwienie Agencji przeprowadzenia wizytacji w miejscu realizacji operacji oraz kontroli (w tym Ministrowi Finansów, Ministrowi Rolnictwa i Rozwoju Wsi, Komisji Europejskiej, organom kontroli skarbowej oraz innym podmiotom upoważnionych do takiej czynności); dostosowanie gospodarstwa w zakresie objętym operacją, nie później niż do dnia złożenia wniosku o płatność ostateczną i nie później niż w terminach określonych Programem, do standardów wynikających z przepisów prawa Unii Europejskiej.

\section{Wykonanie zobowiązania}

3.1. Przedmiot wykonania zobowiązania, termin i tryb wykonania zobowiązania określa umowa. Agencja dokona wypłaty świadczenia pieniężnego (określonej kwoty środków finansowych) w przypadku wykonania świadczenia przez beneficjenta polegającego na zrealizowaniu operacji w całości lub częściami z należytą starannością, której jakość wiążąco określa umowa (wraz z zestawieniem rzeczowo-finansowym operacji stanowiącym załącznik do umowy) - w terminie określonym w umowie. Wypłata świadczenia przez Agencję nastąpi w szczególnym trybie - na wniosek beneficjenta po zakończeniu operacji (zgodnie z warunkami określonymi w umowie, rozporządzeniu ${ }^{29}$ oraz w innych przepisach dotyczących inwesty-

Zgodnie z przepisami § 8 rozporządzenia op. cit. „Pomoc przyznaje się w formie refundacji części kosztów: 1) budowy, przebudowy, remontu połączonego z modernizacją budynków i budowli wykorzystywanych do produkcji rolnej, zakupu maszyn, urządzeń, wyposażenia do produkcji rolnej, zakładania, wyposażania sadów lub plantacji wieloletnich, budowy albo zakupu elementów infrastruktury technicznej wpływających na warunki prowadzenia działalności rolniczej, ogólnych, które są bezpośrednio związane z przygotowaniem i realizacja operacji, poniesionych: od dnia zawarcia umowy, a w przypadku kosztów stanowiących koszty ogólne - poniesionych nie wcześniej niż 1 stycznia 2007 r., w formie rozliczenia pieniężnego, a w przypadku transakcji, której wartość bez względu na liczbę wynikających z niej płatności przekracza 10 tys. zł, lub kosztów, o których mowa w $\S 9$ ust. 5 (tzn. zakupu używanych maszyn lub urządzeń nie przekraczających ich wartości rynkowej oraz ceny nowych podobnych maszyn i urządzeń, jeżeli: 1) w dniu zakupu nie były starsze niż 5-letnie, 2) nie zostały wcześniej nabyte $z$ wykorzystaniem pomocy krajowej lub pochodzącej z Unii Europejskiej, mają właściwości techniczne niezbędne do realizacji operacji i spełniają obowiązujące normy i standardy; ich zakup będzie potwierdzony faktu- 
cji objętych operacją) i po przedstawieniu przez beneficjenta pokwitowania ${ }^{30}$, zgodnie $\mathrm{z}$ regułą art. $462 \S 2 \mathrm{kc}$. Pokwitowanie będą stanowiły dowody (faktury i inne dokumenty) poniesionych przez beneficjenta kosztach kwalifikowanych związanych z operacją, potwierdzające spełnienie świadczenia. ${ }^{31} \mathrm{~W}$ przypadku spełnienia świadczenia tylko częściowo (realizowania operacji etapowo), beneficjent może żądać zaznaczeniem na dokumencie częściowego spełnienia świadczenia. (465 in fine kc.).

Po zakończeniu operacji beneficjent w wykonaniu zobowiązania umownego składa wniosek o płatność (pośrednią lub ostateczną ${ }^{32}$ ) osobiście lub przez umocowaną osobę bezpośrednio w oddziale terenowym Agencji, właściwej ze względu na miejsce realizacji operacji, w terminie określonym w umowie ${ }^{33}$ ( $\$ 25$ rozporządze- $^{-}$ nia w związku z art. $454 \S 1$ zd. 2 kc.). Wniosek jest rozpatrywany w trybie szczególnego postępowania administracyjnego, na podstawie ustawy z 7 marca $2007 \mathrm{r}$. o.w.r.o.w. EFR ROW i rozporządzenia wykonawczego, do którego w sprawach nie uregulowanych odmiennie mają odpowiednio zastosowanie przepisy kodeksu postępowania administracyjnego. Agencja zobowiązana jest do rozpatrzenia wniosku o płatność w terminie 3 miesięcy, licząc od dnia złożenia wniosku o płatność i po pozytywnym jego rozpatrzeniu (weryfikacji przedstawionych faktur i dokumentów potwierdzających poniesione na operację nakłady z zestawieniem rzeczowo-finansowym operacji) - powiadomienia na piśmie beneficjenta. Zatem świadczenie pieniężne stanie się wymagalne niezwłocznie po doręczeniu zawiadomienia beneficjentowi, czyli bez nieuzasadnionej zwłoki - zgodnie z ogólną regułą art. 354 kc.

rą oraz dowodem dokonania płatności bezgotówkowej przeprowadzonej poleceniem przelewy zostały zakupione od podmiotu prowadzącego działalność gospodarczą w zakresie sprzedaży takich maszyn lub urządzeń").

Por. $§ 7$ ust. 4 i § 25 rozporządzenia z 17 października 2007 r. stanowi tryb wypłaty środków finansowych z tytułu pomocy określa umowa, z tym że są one wypłacane po rozpatrzeniu złożonego przez beneficjenta wniosku o płatność

31 Dokumenty potwierdzające poniesione koszty kwalifikowane wymieniono w $\S 9$ rozporządzenia wykonawczego.

32 W rozumieniu $\S 7$ ust. 6 rozporządzenia op. cit. Przez wniosek o płatność pośrednią - rozumie się wniosek o płatność składany po zrealizowaniu każdego z etapów operacji, jeżeli dany etap nie jest etapem końcowym; przez płatność ostateczna - rozumie się wniosek o płatność składany po zrealizowaniu całej operacji. Terminy składania wniosku o płatność określaja przepisy $\S 7$ ust. 4 i § 5 rozporządzenia op. cit. „ust 4 . Pomoc przyznaje się, jeżeli: 1) operacja będzie realizowana w nie więcej niż dwóch etapach; 2) złożenie wniosku o płatność pośrednią nastapi w terminie 24 miesięcy od dnia zawarcia umowy; 3) zakończenie realizacji operacji i złożenie wniosku o płatność ostateczną nastapi w terminie: a) 36 miesięcy od dnia zawarcia umowy - w przypadku operacji realizowanych w dwóch etapach, b) 24 miesięcy od dnia zawarcia umowy - w przypadku operacji realizowanej w jednym etapie - lecz nie później niż do dnia 30 czerwca 2015 r.; 4) płatność ostateczna będzie obejmować nie mniej niż 25\% łącznej planowanej wysokości pomocy.” ust. 5 „W przypadku operacji obejmujących inwestycje polegające na nabyciu rzeczy będących przedmiotem leasingu: pomoc przyznaje się: jeżeli operacja będzie realizowana w nie więcej niż 10 etapach, przy czym w odniesieniu do części operacji obejmującej wyłącznie inwestycje nie polegające na nabyciu rzeczy będących przedmiotem leasingu realizowana w dwóch etapach; b) złożenie wniosku o płatność pośrednią nastapi w terminie 12 miesięcy od dnia zawarcia umowy, przy czym złożenie wniosku o pierwszą płatność pośrednią w odniesieniu do części inwestycji obejmującej wyłącznie inwestycje nie polegające na nabyciu rzeczy będących przedmiotem leasingu nastapi w terminie 24 miesięcy od dnia zawarcia umowy; c) wniosek o płatność będzie składany nie częściej niż dwa razy w roku; d) zakończenie realizacji operacji i złożenie wniosku o płatność ostateczną nastapi w terminie 60 miesięcy od dnia zawarcia umowy, lecz nie później niż do dnia 30 czerwca 2015 r., przy czym złożenie ostatniego wniosku o płatność w odniesieniu do części operacji obejmujących wyłącznie inwestycje nie polegające na nabyciu rzeczy będących przedmiotem leasingu nastapi w terminie określonym w ust. 4 pkt. 3". 
W wyjątkowych przypadkach, określonych w umowie, okolicznością uzasadnioną jest opóźnienie otrzymania przez Agencję środków finansowych na wypłatę pomocy bądź przedłużające się postępowanie administracyjne w sprawie o płatność, związane z koniecznością uzyskania dodatkowych wyjaśnień lub opinii innego podmiotu, lub jeśli zajdą nowe okoliczności budzące wątpliwości co do możliwości wypłaty pomocy.

Wypłata świadczenia pieniężnego nastąpi przelewem na rachunek bankowy beneficjenta w wysokości określonej w umowie, nie wyższej niż wykazana w zestawieniu rzeczowo-finansowym operacji stanowiącym załącznik do umowy. Zobowiązania stron umowy przyznania pomocy wygasają z chwilą osiągnięcia celu określonego w umowie i wypłatą świadczenia pieniężnego na podstawie wniosku o płatność ostateczną.

3.2. Zmiana postanowień umowy jest dopuszczalna w przypadkach określonych ustawą (art. 23 ust. 2 i 3), rozporządzeniem i umową, na wniosek i za zgodą każdej ze stron umowy, z zachowaniem zastrzeżonej formy pisemnej pod rygorem nieważności. Zmiana postanowień umowy dotyczących istotnych elementów przedmiotu świadczenia nie może dotyczyć: a) zwiększenia określonej w umowie procentowej wysokości kwoty świadczenia pieniężnego (pomocy); b) zmiany celu operacji; c) zmiany zobowiązania o niefinansowania operacji z udziałem innych środków publicznych, przyznanych w związku z realizacją tej operacją. Ich naruszenie skutkuje nieważnością umowy przyznania pomocy.

Zmiana określonego w umowie przedmiotu świadczenia na inny (jego modyfikacja) jest możliwa już po powstaniu zobowiązania za zgodą Agencji, która tym samym wyrazi zgodę na takie wykonanie, które zostanie uznane za wypełniające zobowiązanie (art. $453 \mathrm{kc}$.). Dotyczy ono: a) zmian w zestawieniu rzeczowo-finansowym operacji (stanowiącym załącznik do umowy) związanych ze zmniejszeniem zakresu lub wysokości kosztów kwalifikowanych operacji na poszczególnym etapie, b) zmian zakresu rzeczowego operacji w zestawieniu rzeczowo-finansowym operacji ${ }^{34}$, c) zmiany terminu złożenia wniosku o płatnośćc ${ }^{35}$, d) zmiany wykazu działek ewidencyjnych, na których realizowane są w ramach operacji inwestycje trwale związane z nieruchomością. ${ }^{36}$

3.3. Przejście praw i obowiązków wynikających z umowy o pomoc na następcę prawnego w czasie trwania stosunku zobowiązaniowego jest bezpośrednim skutkiem postanowień ustawy z 7 marca 2007 r. Przejście praw i obowiązków w czasie

34

35

36
Wniosek składa beneficjent najpóźniej w dniu złożenia wniosku o płatność.

Na wniosek beneficjenta złożony najpóźniej na 40 dni kalendarzowych przed upływem terminu określonego w umowie.

Na wniosek beneficjenta złożony przed planowaną zmianą albo najpóźniej w dniu złożenia wniosku o płatność ostateczną dla operacji jednoetapowych lub w dniu złożenia wniosku o płatność pośrednią w ramach etapu, w którym dokonana została zmiana działek, na których realizowane są inwestycje trwale z gruntem związane. 
realizacji operacji lub w okresie 5 lat od daty płatności ostatecznej nastąpi wyłącznie w uzasadnionych przypadkach i na warunkach określonych w ustawie, rozporządzeniu wykonawczym i umowie.

Należą do nich: 1) śmierć beneficjenta (osoby fizycznej), rozwiązanie osoby prawnej lub jednostki organizacyjnej nieposiadającej osobowości prawnej lub inne zdarzenie prawne, w wyniku którego zaistnieje następstwo prawne, 2) zbycie całości lub części gospodarstwa rolnego, całości lub części przedsiębiorstwa rolnego w ramach następstwa prawnego lub przekształcenie przedsiębiorstwa ${ }^{37}$ lub 3) zmiana postanowień umownych dotyczących zobowiązań związanych z: a) przenoszeniem posiadania lub prawa własności nabytych dóbr, wybudowanych, przebudowanych, zmodernizowanych budynków lub budowli, na które została przyznana i wypłacona pomoc oraz wykorzystana z godnie z przeznaczeniem i celem operacji; b) prowadzeniem działalności, której służyła realizacja operacji, lub której prowadzenie stanowiło warunek przyznania pomocy, bez zmiany miejsca jej wykonania; c) prowadzeniem działalności rolniczej bez zmiany miejsca jej wykonania. Zmiana postanowień umownych nastąpi po uprzednim pozytywnym rozpatrzeniu wniosku beneficjenta, $\mathrm{z}$ jednoczesnym wskazaniem zakresu wnioskowanych zmian albo okoliczności faktycznych i prawnych wykluczających dokonanie zmian postanowień umowy. Brak zgody na dokonanie wnioskowanych zmian postanowień umowy skutkuje obowiązkiem zwrotu nienależnie pobranego świadczenia pieniężnego.

\section{Skutki niewykonania lub nienależytego wykonania umowy}

Zabezpieczeniem należytego wykonania przez beneficjenta zobowiązań określonych w umowie przyznania pomocy jest weksel in blanco (niezupełny) wraz $\mathrm{z}$ deklaracją wekslową ${ }^{38}$. Agencja zwróci weksel beneficjentowi po wykonaniu zobowiązań określonych w umowie, po upływie 5 lat od dnia wypłaty przez Agencję płatności ostatecznej. W pozostałych przypadkach: rozwiązania umowy przed dokonaniem wypłaty pomocy; odmowy wypłaty całości pomocy; zwrotu przez beneficjenta całości otrzymanej pomocy wraz z należnymi odsetkami; przejęcia zobowiązań umownych przez nabywcę lub następcę prawnego gospodarstwa rolnego lub przedsiębiorstwa rolnego - Agencja jest zobowiązana do niezwłocznego zwrotu weksla beneficjentowi.

Za zbycie uważa się przeniesienie własności lub posiadania gospodarstwa rolnego (gospodarstwa rolnego) lub jego części, pod warunkiem, że nabywca lub następca prawny spełni warunki przyznania pomocy i wypłaty pomocy oraz przedstawi dokumenty potwierdzające nabycie gospodarstwa rolnego lub przedsiębiorstwa, albo przekształcenia przedsiębiorstwa, albo sprzedaży i kupna rzeczy stanowiących przedmiot operacji, a także dokumenty potwierdzające przejęcie przez nabywcę lub następcę prawnego zobowiązań związanych z przyznaną beneficjentowi pomoca, w szczególności umowę przystapienia do długu. Oraz inne dokumenty określone w rozporządzeniu. wraz ze wzorcem umowy; jest podpisany przez beneficjenta w obecności upoważnionego pracownika Agencji i złożony w oddziale regionalnym w dniu zawarcia umowy. 
Niewykonanie lub nienależyte wykonanie (w części lub całości) postanowień umownych skutkuje: 1) rozwiązaniem umowy za wypowiedzeniem, niezwłocznie oraz 2) zwrotem nienależnie lub nadmiernie pobranego świadczenia w części lub całości.

4.1. Zwrot nienależnie lub nadmiernie pobranego świadczenia w części lub całości, w następującym przypadku: a) nieosiągnięcia lub niezachowania celu operacji; b) ustalenia niezgodności realizowanej operacji z Programem, ustawą, rozporządzeniem, umową lub odrębnymi przepisami; c) rezygnacji beneficjenta z realizacji operacji; d) wykluczenia beneficjenta $\mathrm{z}$ ubiegania się o przyznanie pomocy na podstawie przepisów odrębnych; e) wystąpienia okoliczności skutkujących rozwiązaniem umowy przyznania pomocy; f) rozpoczęcia realizacji operacji przed dniem zawarcia umowy, tj. w 2007 r.; g) przestępstwa przeciwko dokumentom lub oświadczeniom mających wpływ na przyznanie lub wypłatę pomocy; h) niespełnienia co najmniej jednego ze zobowiązań umownych; i) innych władczych rozstrzygnięć organów lub orzeczeń sądowych stwierdzających popełnienie przez beneficjenta czynów zabronionych przepisami odrębnymi.

Zwrot nienależnie lub nadmiernie pobranego świadczenia w części lub całości nastąpi w wysokości (lub części) pobranego świadczenia pieniężnego wraz z odsetkami, za okres między otrzymaniem przez beneficjenta powiadomienia o konieczności zwrotu a dokonaniem przez niego zwrotu. Zwrot nastąpi w terminie 14 dni od dnia doręczenia wezwania do zapłaty. ${ }^{39}$

4.2. Rozwiązanie umowy przyznania pomocy za wypowiedzeniem następuje niezwłocznie, po spełnieniu jednej z następujących przesłanek: 1) nierozpoczęcia przez beneficjenta realizacji operacji w całości lub części do końca terminu określonego w umowie przyznania pomocy, który poprzedza termin złożenia wniosku o płatność; 2) niezłożenia wniosku o płatność w terminie wyznaczonym w umowie oraz po bezskutecznym upływie dwóch dodatkowych terminów wyznaczonych z urzędu przez Agencję; 3) odstąpienia przez beneficjenta: a) od operacji lub b) od realizacji zobowiązań wynikających z umowy, po wypłacie pomocy, tzn. gdy nie zrealizował on operacji lub jej etapu, w tym: - nie poniósł kosztów z nią związanych, zgodnie $\mathrm{z}$ warunkami określonymi w umowie, rozporządzeniu i innych przepisach; - nie zrealizował zobowiązań określonych w umowie; - nie udokumentował związanych z operacją lub jej etapem poniesionych kwalifikowanych kosztów lub naruszył warunki przyznania pomocy; 4) stwierdzenia, że: a) w okresie realizacji operacji, w okresie 5 lat od dnia dokonania przez Agencję płatności ostatecznej nastąpiły nieprawidłowości, polegające na wyłączeniu gospodarstwa rolnego stapowiednio zastosowanie przepisy ustawy z dnia 29.12.1993 r. o utworzeniu Agencji Restrukturyzacji i Modernizacji Rolnictwa. Tekst jednolity: Dz.U. z 2005 r. Nr 31, poz. 264 ze zm. 
nowiącego przedmiot współwłasności osób fizycznych, z ubiegania się o przyznanie pomocy lub beneficjent nie wywiązał się z obowiązków umowy (nie poniósł kosztów stanowiących podstawę rozliczenia, b) beneficjent sfinansował operację z udziałem innych środków publicznych, przyznanych w związku z realizacją tej operacji; c) w trakcie realizacji tej operacji oraz przez okres 5 lat od dnia dokonania przez Agencję płatności ostatecznej przeniósł posiadanie lub prawo własności nabytych dóbr, budynków i budowli, na które była przyznana i wypłacona pomoc oraz je wykorzystał niezgodnie z przeznaczeniem; - prowadził działalność niesłużącą realizacji operacji; d) wystąpiły inne okoliczności (np. nieosiągnięcie lub zachowanie celu operacji, rezygnacja beneficjenta z realizacji operacji, jego wykluczenie z ubiegania się o pomoc na podstawie odrębnych przepisów).

Spory powstałe między stronami umowy przyznania pomocy rozstrzygane są przez sąd powszechny właściwy dla siedziby Agencji. 


\section{Construction fundamentals of the agreement on support schemes (aid granting) by the European Agricultural Fund for Rural Development}

\section{Summary}

In the agricultural sector, unlike in any other economic area, agricultural agreements (contracts) should reflect their social character since they are used to put in order and reconcile varied interests. However the agreements used in the Polish agricultural transactions are of an extremely varied character (sale, exchange, donation, life usufruct, succession agreement, the agreement of farm conveyance for structural pension, lease, renting, contract deliveries of agricultural produce). In practice they are concluded in order to create, enlarge or arrange a farm from a subject matter point of view. With the Act of 7 March 2007 on the support for rural areas with the participation of means from the European Agricultural Fund for Rural Development there was introduced a new type of contracts constructed in order to acquire payments from the European means within support schemes for rural development, with contracts on granting payments constituting this type of agreement. The agreement on granting payments is of civil-legal nature which can be included into agricultural agreements. It is an innominate bilaterally binding mutual contract, with the reservation of a written form ad solemnitatem under the clause of nullity. In agricultural transactions its contents were expressed in the models of agreements on granting support (aid) for activities specified in article 5 of the act. Binding a contractual relationship occurs strictly in accordance with the pattern of the support granting contract. In the article there were presented construction fundamentals of such a contract (contracting parties, parties' rights and obligations, contents, fulfilment of an obligation, non-fulfilment or improper fulfilment of a contract, withdrawal from a contract or its dissolution). 